\title{
Technical note: Evaluating nuclear magnetic resonance spectroscopy for determining body composition in Holstein dairy calves using deuterium oxide dilution methods
}

\author{
C. E. Chapman, ${ }^{* 1}$ P. Stone Wilkinson, $†$ M. R. Murphy, $\ddagger$ and P. S. Erickson ${ }^{* 2}$ \\ *Department of Biological Sciences, and \\ †Chemistry Department, University of New Hampshire, Durham 03824 \\ ‡Department of Animal Sciences, University of Illinois, Urbana 61820
}

\begin{abstract}
Deuterium oxide $\left(\mathrm{D}_{2} \mathrm{O}\right)$ dilution methods have been used to assess body composition in live animals. Estimated body water content can be used to predict body fat and protein, and thus, the amount of energy reserves. It is an alternative method to direct chemical analysis and considered a noninvasive technique that is economical and repeatable. Deuterium oxide use is considered easy, safe, and accurate; however, the traditional methods of analyzing $\mathrm{D}_{2} \mathrm{O}$ are expensive, tedious, and time consuming. The objective of this study was to evaluate the potential for using nuclear magnetic resonance spectroscopy (NMR) to determine body composition in Holstein dairy heifers. Nuclear magnetic resonance is less expensive and requires minutes to calculate the percentage of $\mathrm{D}_{2} \mathrm{O}$ in the blood. This study used 24 newborn dairy heifer calves blocked by birth and randomly assigned to 1 of 3 treatments: (1) $446 \mathrm{~g}$ dry matter (DM) of a conventional milk replacer (MR) [CON; $20 \%$ crude protein (CP), 20\% fat], (2) $669 \mathrm{~g}$ DM of a moderately high protein MR (MOD; $26 \%$ CP, $18 \%$ fat), or (3) 892 g DM of a moderately high protein MR (aggressive, AGG; $26 \%$ CP, 18\% fat). All calves had free-choice access to starter and water. Both MR and starter were medicated with decoquinate. During weaning (d 43 to 49), the morning MR feeding ceased. On d 50, all MR feedings ended but starter and water intakes were continuously recorded until d 56 . When calves were $50 \mathrm{~d}$ of age, a baseline blood sample was taken followed by injection of $300 \mathrm{mg}$ of $\mathrm{D}_{2} \mathrm{O} / \mathrm{kg}$ of body weight in sterile physiological saline $(0.9 \%)$. The syringes containing the $\mathrm{D}_{2} \mathrm{O}$ in physiological saline were weighed before and after administration to record

\footnotetext{
Received August 18, 2016.

Accepted December 14, 2016.

${ }^{1}$ Current address: Penn State Extension-Bradford County, Towanda,

${ }^{2}$ Corresponding author: peter.erickson@unh.edu
} PA 18848
\end{abstract}

the actual dose of $\mathrm{D}_{2} \mathrm{O}$ injected gravimetrically. After injection, the $\mathrm{D}_{2} \mathrm{O}$ was allowed to equilibrate with body water for $1 \mathrm{~h}$. Six blood samples were taken over $6 \mathrm{~d}$ $(1 / \mathrm{d})$ at $1630 \mathrm{~h}$ to estimate the dilution of the tracer. The plasma was aspirated and stored at $-20^{\circ} \mathrm{C}$ until further $\mathrm{D}_{2} \mathrm{O}$ analysis. This new method was validated using 4 calf plasma samples that were sent to an outside laboratory for measurement using an independent validation method. We detected no differences in total body water, protein, fat, or mineral content in calves fed CON, MOD, or AGG; however, results demonstrated that the $\mathrm{D}_{2} \mathrm{O}$ dilution technique and analysis by NMR is an appropriate and easy method to estimate water, protein, ash, and fat in young heifers.

Key words: deuterium oxide, nuclear magnetic resonance, body composition, heifer

\section{Technical Note}

The composition of lean body mass is relatively constant across species, and knowing body water content can be used to understand the composition of body fat, protein, and minerals (Byers, 1979). Water makes up about $73 \%$ of the lean body; it is the largest component and has become the choice for measuring body composition; however, measurement of the size and kinetics of aqueous pools in the digesta of ruminants is complicated by unknown contributions of variable magnitude from the digestive tract (Byers, 1979). Deuterium oxide $\left(\mathrm{D}_{2} \mathrm{O}\right)$ methods have been used to differentiate these pools such that other body compartments can be estimated for growth (Byers, 1979).

Traditionally, the most accurate way of determining body composition was to slaughter the animal and then grind and analyze the entirety of the animal's tissues (Jesse et al., 1976). This method is precise but precludes measurement of further growth. In order to measure changes in composition over time, studies have conducted serial slaughter techniques where a large population of similar animals are allocated to treat- 
ments with a representative group on each treatment slaughtered at desired intervals of time or size (Byers, 1979). However, this method assumes that all animals are similar in body composition and that all respond similarly to treatments, making this method less accurate or valid. It is necessary to develop methods to precisely estimate body composition and composition of growth as it occurs in the live animal.

Numerous indirect methods have been used to determine total body water and are based on the dilution principle of water-soluble tracers such as antipyrine or urea, but they give rise to errors because tracers are bound to proteins, are rapidly metabolized and excreted, or are slowly and incompletely distributed to all the body water components (Novak, 1967; Schoeller et al., 1980). The best and most frequently used tracers have been water labeled with either tritium or deuterium (Novak, 1967; Schoeller et al., 1980); however, the use of deuterium has the disadvantage of tedious and timeconsuming analysis, whereas the use of tritium involves a radiation hazard (Schoeller et al., 1980).

Deuterium oxide dilution methods can be used to predict estimated body water content, which can then be used to predict body fat and protein (Panaretto and Till, 1963). Deuterium oxide dilution methods for estimation of total body water have been used for assessment of body composition for many species including pigs, beef steers, dairy cows, dairy heifers, sheep, and goats (Novak, 1967; Shipley and Clark, 1972; Byers, 1979; Schoeller et al., 1980; Shields et al., 1983; Andrew et al., 1995; Auchtung et al., 2002; Rius et al., 2005) and are considered noninvasive techniques that are economical and repeatable. The $\mathrm{D}_{2} \mathrm{O}$ dilution method measures the body water turnover rate and is safe, nonradioactive, and accurate. It was the method used to measure body water turnover in doubly labeled water studies of long-term metabolic rate (Schoeller et al., 1980). Estimated body water content can be used to predict body fat and protein, and thus, the amount of energy reserves (Panaretto and Till, 1963). Panaretto and Till (1963) found that total body fat and total body water were inversely correlated in mature castrated male goats $(\mathrm{r}=-0.97)$. Rius et al. (2005) compared $\mathrm{D}_{2} \mathrm{O}$ methods and direct chemical analysis to assess body composition at 5 and 7 mo of age. In 5-moold heifers, correlations between estimates of body protein, water, and mineral contents as determined by $\mathrm{D}_{2} \mathrm{O}$ dilution methods and direct chemical analysis of body tissue were $0.86,0.85$, and 0.76 , respectively, but fat values were not correlated $(\mathrm{r}=-0.068)$. Those authors were unable to accurately estimate body composition using the $\mathrm{D}_{2} \mathrm{O}$ dilution method for 7-mo-old heifers and attributed this to the gastrointestinal tract in young animals not being fully developed.
Studies have demonstrated that feeding calves a milk replacer (MR) with $>25 \% \mathrm{CP}$ at an increasing rate with age up to 900 to $1,200 \mathrm{~g}$ of $\mathrm{DM} / \mathrm{d}$ can facilitate rapid and efficient early lean growth and allow for increased body protein deposition and growth rate without excessive fattening (Diaz et al., 2001; Tikofsky et al., 2001; Blome et al., 2003; Bartlett et al., 2006). However, in these studies, calves were slaughtered. Using $\mathrm{D}_{2} \mathrm{O}$ might be an easy, inexpensive, and valid method for determining the composition of growth in calves fed using these aggressive MR feeding programs instead of direct chemical analysis. Deuterium oxide dilution methods will also allow for measurement of further growth. To date, nuclear magnetic resonance spectroscopy (NMR) has not been used to estimate body composition through $\mathrm{D}_{2} \mathrm{O}$ dilution methods in animals. An NMR-based method has been used to determine total body water in humans (Khaled et al., 1987). Those authors validated the method against a standard infrared absorption procedure using a tracer dose of $\mathrm{D}_{2} \mathrm{O}$ and concluded that the NMR method was fast, accurate, needed only a small dose of $\mathrm{D}_{2} \mathrm{O}$, and did not require any sample preparation. The objective of the current study was to evaluate the potential for using NMR to determine body composition in Holstein dairy heifers.

Twenty-four Holstein heifer calves (initial BW, mean $\pm \mathrm{SD})$ of $41.6 \pm 4.8 \mathrm{~kg}$ were blocked by birth date and randomly assigned at birth to 1 of 3 treatments in a randomized complete block design. The treatments were (1) $446 \mathrm{~g}$ DM of a conventional MR (CON; $20 \%$ CP, 20\% fat), (2) 669 g DM of a moderately high protein MR (MOD; 26\% CP, 18\% fat), or (3) 892 g DM of a moderately high protein MR (aggressive, AGG; $26 \%$ CP, 18\% fat). Both MR products were provided by Provimi North America (Brookville, $\mathrm{OH}$ ) and medicated with decoquinate. The 56-d study was conducted from August 2013 to March 2014. Calves were fed a $20.7 \%$ CP textured starter (Provimi North America) and water ad libitum starting at $2 \mathrm{~d}$ of age and continuing for the entire 56-d trial. Initial BW and skeletal measurements were taken before calves started MR treatment. Calves on CON were fed $227 \mathrm{~g}$ of 20:20 (CP:fat) MR reconstituted to $10.7 \%$ solids (at 0800 and $1700 \mathrm{~h}$ ) from d 2 to 42 (1.89 L twice daily). Calves on MOD were fed $340 \mathrm{~g}$ of 26:18 (CP:fat) MR reconstituted to $13 \%$ solids (at 0800 and $1700 \mathrm{~h}$ ) from d 2 to 42 (2.27 L twice daily). Calves on AGG were fed $340 \mathrm{~g}$ of 26:18 (CP:fat) MR reconstituted to $13 \%$ solids (at 0800 and $1700 \mathrm{~h})$ from d 2 to $6(2.27 \mathrm{~L}$ twice daily) and then $454 \mathrm{~g}$ of $26: 18$ (CP:fat) MR reconstituted to $13 \%$ solids (at 0800 and $1700 \mathrm{~h}$ ) from d 7 to $42(3.03$ L twice daily). On d 43 to 49, calves on all treatments were fed once daily at $0800 \mathrm{~h}$. Calves were fed MR and 
water in pails. On d 50, all milk feedings ceased. Calves remained on trial for $7 \mathrm{~d}$ after weaning for a total of 56 d. Results from the intake, growth, digestibility, and $\mathrm{N}$ efficiency are reported in Chapman et al. (2017).

When calves turned $50 \mathrm{~d}$ of age, calves were weighed on a platform scale (VS-2000, A and A Scales LLC, Prospect Park, NJ) to determine the required dose of $\mathrm{D}_{2} \mathrm{O}$ (99.9 atom \% D, Sigma-Aldrich Corp., St. Louis, $\mathrm{MO})$. Blood samples were collected via jugular venipuncture using 10-mL tubes (BD Vacutainer, Becton Dickinson, Franklin Lakes, NJ) containing sodium heparin using 22-gauge needles. A baseline blood sample was immediately followed by injection of $300 \mathrm{mg}$ of $\mathrm{D}_{2} \mathrm{O} / \mathrm{kg}$ of $\mathrm{BW}$ in sterile physiological saline $(0.9 \%)$. The syringes containing the $\mathrm{D}_{2} \mathrm{O}$ in physiological saline were weighed before and after administration to record the actual dose of $\mathrm{D}_{2} \mathrm{O}$ injected gravimetrically. After injection, the $\mathrm{D}_{2} \mathrm{O}$ was allowed to equilibrate with body water for $1 \mathrm{~h}$. Six blood samples were taken over $6 \mathrm{~d}$ $(1 / \mathrm{d})$ at $1630 \mathrm{~h}$ to estimate the dilution of the tracer. Blood samples were centrifuged at $1,278 \times g$ at $4^{\circ} \mathrm{C}$ for 20 min (5430R, Eppendorf, Hamburg, Germany). The plasma was aspirated and stored at $-20^{\circ} \mathrm{C}$ until $\mathrm{D}_{2} \mathrm{O}$ analysis.

For analysis of $\mathrm{D}_{2} \mathrm{O}$, plasma samples were thawed and aliquots $(750 \mu \mathrm{L})$ of plasma were transferred to 5-mm borosilicate glass NMR tubes (Wilmad LabGlass, Vineland, NJ). All ${ }^{2} \mathrm{H}$ NMR spectra were acquired on a Varian Unity INOVA 500 NMR spectroscope (Varian, Palo Alto, CA) equipped with a broadband probe and tuned to the deuterium $\left({ }^{2} \mathrm{H}\right)$ resonance frequency $(76.71$ $\mathrm{MHz}$ ). Quantitative experimental parameters included a 1.7-s relaxation delay, 4.3-s acquisition time, and a fixed receiver gain for all data sets. Standards of 0 , $0.229,0.446$, and $0.901 \mathrm{mg} / \mathrm{mL} \mathrm{D}_{2} \mathrm{O}$ were prepared and analyzed by NMR before the calf plasma samples to generate a standard curve. The deuterium peak of the $\mathrm{D}_{2} \mathrm{O}$ was reference to $4.79 \mathrm{ppm}$ (Fulmer et al., 2010). Data processing and analysis were performed using Mnova NMR processing software (Mestrelab Research, Escondido, CA). The deuterium resonance of $\mathrm{D}_{2} \mathrm{O}$ at $4.79 \mathrm{ppm}$ was integrated and the absolute integration values reported. Chemical shifts are reported in parts per million relative to $\mathrm{D}_{2} \mathrm{O}$ at $25^{\circ} \mathrm{C}$ and the deuterium chemical shifts scale was assumed to be identical to proton.

The percentage of $\mathrm{D}_{2} \mathrm{O}$ found in the calf plasma was calculated from the standard curve. Baseline plasma samples taken before injection of $\mathrm{D}_{2} \mathrm{O}$ had traces of $\mathrm{D}_{2} \mathrm{O}$; these were subtracted from each of the plasma samples taken after $\mathrm{D}_{2} \mathrm{O}$ injection to account for background. The natural logarithm of each calf's plasma sample $\mathrm{D}_{2} \mathrm{O}$ concentration was then plotted to determine the best-fit line of the $\mathrm{D}_{2} \mathrm{O}$ dilution curve (Figure

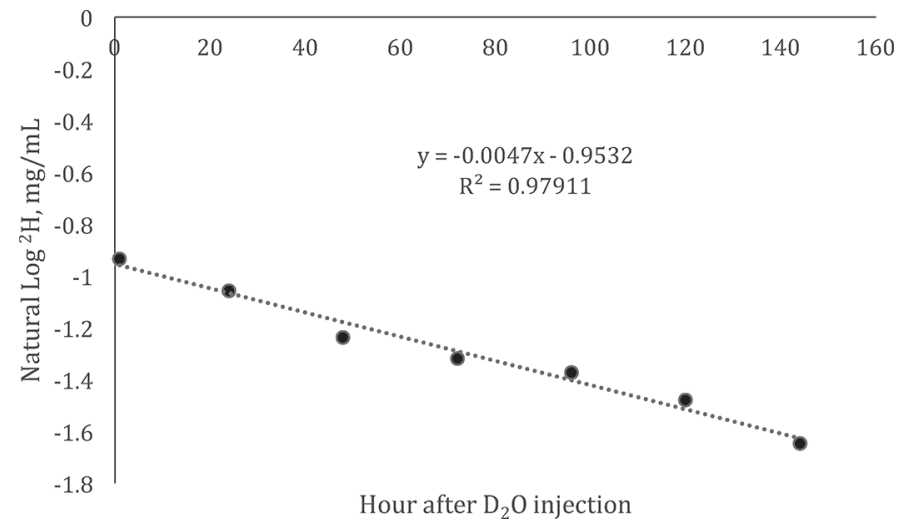

Figure 1. Example of calf deuterium $\left({ }^{2} \mathrm{H}\right)$ plasma concentration versus time after deuterium oxide $\left(\mathrm{D}_{2} \mathrm{O}\right)$ injection.

1). Total body water was calculated using the amount of $\mathrm{D}_{2} \mathrm{O}$ injected into the calf and dividing it by the $\mathrm{y}$ intercept. Body water percentage was then calculated by dividing the total body water by the mass of the calf. Determinations of total body protein and total body fat were made using the equations described by Panaretto and Till (1963).

Estimates of body of water, fat, $\mathrm{CP}$, and ash were analyzed as a randomized complete block design using the MIXED procedure of SAS (version 9.4; SAS Institute Inc., Cary, NC) according to the following model:

$$
Y_{i j}=\mu+B_{i}+T_{j}+E_{i j},
$$

where $Y_{i j}=$ the dependent variable; $\mu=$ the overall mean; $B_{i}=$ the random effect of block $i(i=1, \ldots, 8)$; $T_{j}=$ the effect of MR type or amount, the $j$ th treatment (CON, MOD, or AGG); $E_{i j}=$ the residual error $\sim N\left(0, \sigma_{e}^{2}\right)$, and $\sigma^{2}$ is the population standard deviation and $e$ is Euler's number, the base of the natural logarithm.

Degrees of freedom were calculated using the Kenward-Roger approximation option of the MIXED procedure. Least squares means were determined for each treatment and the Tukey's option of SAS was selected to differentiate least squares means among treatments. Significant treatment effects were determined at a probability of $P \leq 0.05$ and trends were defined as: $0.05<P \leq 0.10$.

Results are shown in Table 1 . We detected no differences in total body water, protein, fat, or mineral content in calves fed CON, MOD, or AGG. Four calf samples were sent to Metabolic Solutions Inc. (Nashua, $\mathrm{NH}$ ) to validate the NMR analysis of $\mathrm{D}_{2} \mathrm{O}$ in calf plasma samples by cavity ring-down spectroscopy (CRD). Plasma samples were analyzed for deuterium enrichment by CRD spectroscopy using a liquid water 
isotope analyzer with automated injection system, version 2 upgrade (Los Gatos Research, Mountain View, CA). Before analysis, plasma proteins were removed by adding approximately $5 \mathrm{mg}$ of zinc sulfate monohydrate to 25 to $50 \mu \mathrm{L}$ of plasma in a microcentrifuge tube. Samples were mixed and centrifuged at $4,700 \times$ $g$ to precipitate the proteins. The plasma protein-free supernatant was injected 6 times and the average of the last 3 measurements used for data analysis. A standard curve was run before and after samples to calculate deuterium enrichment as delta per mil (parts per thousand) relative to Vienna Standard Mean Ocean Water (VSMOW). Intra-run precision was less than 2 delta per mil (parts per thousand) and inter-run precision was less than 3.5 delta per mil. The 4 calf $\mathrm{D}_{2} \mathrm{O}$ plasma data from CRD analysis showed total body water percentages of $76.5,75.2,77.8$, and $70.7 \%$, and the results for the current study using NMR were 67.5, 74.5, 77.7, and $77.0 \%$, respectively. Figure 2 shows the validation of the NMR method used in the current study versus the CRD method. This figure shows an $\mathrm{R}^{2}$ of 0.947 , signifying a strong correlation between the 2 methods for analyzing deuterium in calf plasma. Figure 3 shows the residuals of the CRD from the current NMR method used in this study. The majority of data points observed are below zero, which indicates that the NMR method in the current study was more sensitive than CRD at detecting deuterium in calf plasma samples. This is a valid method for estimating body composition of dairy calves as it involves only one step (thus, lowering the error) and accounts for background deuterium occurring naturally in the environment.

Many studies have shown that body composition followed a similar pattern when $\mathrm{D}_{2} \mathrm{O}$ dilution methods were compared with direct chemical analysis. Rius et al. (2005) observed correlations between estimates of

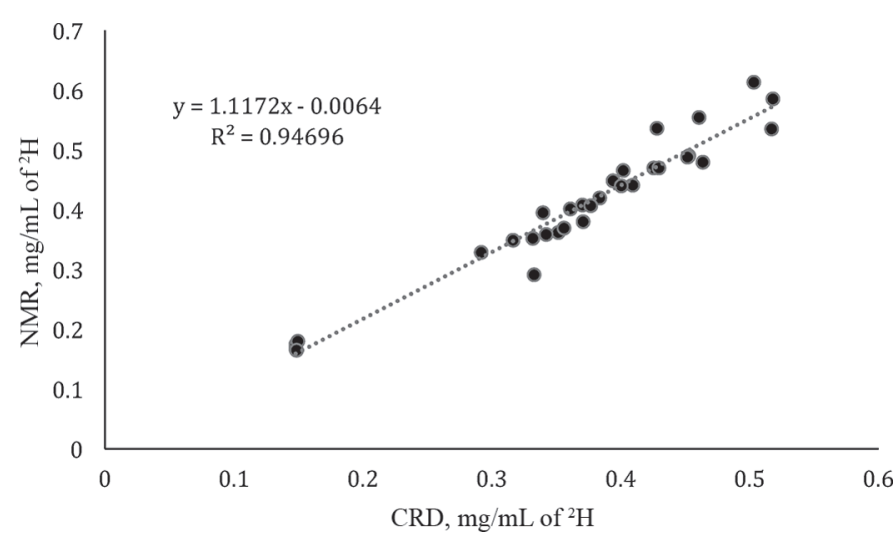

Figure 2. Quantity of deuterium $\left({ }^{2} \mathrm{H}\right)$ in 31 calf plasma samples comparing cavity ring-down spectroscopy (CRD) and nuclear magnetic resonance spectroscopy (NMR).
Residuals

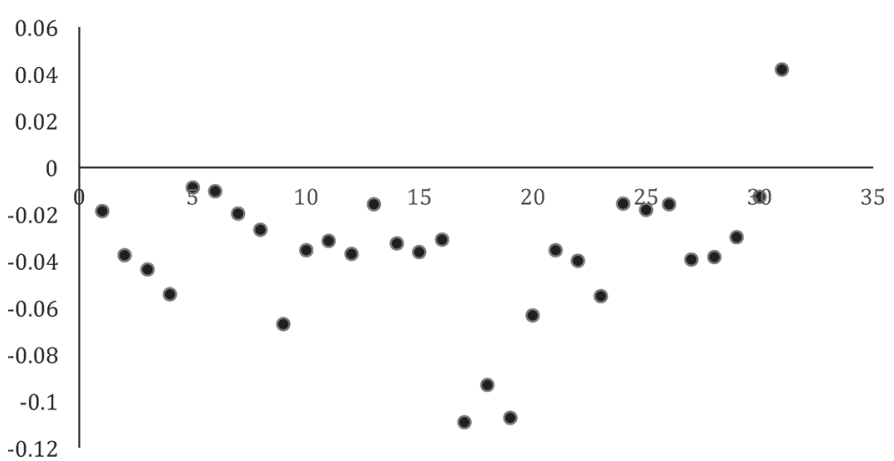

Figure 3. Residuals of deuterium $\left({ }^{2} \mathrm{H}\right)$ in 31 calf plasma samples [cavity ring-down spectroscopy (CRD) - nuclear magnetic resonance spectroscopy (NMR)]. The y-axis shows the quantity of ${ }^{2} \mathrm{H}$ in milligrams per milliliter from CRD minus quantity of ${ }^{2} \mathrm{H}$ in milligrams per milliliter from NMR.

body protein, water, and mineral contents. Auchtung et al. (2002) used $\mathrm{D}_{2} \mathrm{O}$ dilution methods to determine milk intake in calves and found that a smaller number of samples was sufficient to obtain an accurate $\mathrm{D}_{2} \mathrm{O}$ dilution curve compared with Woodford et al. (1984), who collected blood samples every $10 \mathrm{~min}$ for the first $4 \mathrm{~h}$ after injection of $\mathrm{D}_{2} \mathrm{O}$. Auchtung et al. (2002) only collected 2 blood samples after the $\mathrm{D}_{2} \mathrm{O}$ was allowed to equilibrate with body water for $2 \mathrm{~h}$. This was attributed to the gastrointestinal tract in young animals not being fully developed.

Commonly, the analysis of $\mathrm{D}_{2} \mathrm{O}$ in plasma consists of detection of $\mathrm{D}_{2} \mathrm{O}$ by infrared spectroscopy using the procedure of Byers (1979) as well as other methods; however, these methods are laborious and can be costly. Nuclear magnetic resonance spectroscopy is a viable and easy option to quantify $\mathrm{D}_{2} \mathrm{O}$ in plasma for body

Table 1. Body composition of Holstein calves fed 1 of 3 milk replacer (MR) programs ${ }^{1}$ estimated using deuterium oxide dilution methods and analyzed with nuclear magnetic resonance spectroscopy

\begin{tabular}{lccccc}
\hline \multicolumn{5}{c}{ Treatment } & \\
Variable & CON & MOD & AGG & SEM & $P$-value \\
\hline Water, \% & 69.5 & 68.4 & 71.6 & 1.22 & 0.19 \\
Ash, \% & 3.67 & 3.91 & 3.12 & 0.28 & 0.15 \\
CP, \% & 17.7 & 17.4 & 18.3 & 0.32 & 0.16 \\
Fat, \% & 9.15 & 10.2 & 6.95 & 1.25 & 0.19 \\
BW, kg & 67.6 & 69.8 & 73.8 & 3.06 & 0.38 \\
Water, kg & 47.9 & 47.4 & 52.2 & 2.37 & 0.31 \\
Ash, kg & 2.47 & 2.81 & 2.27 & 0.26 & 0.31 \\
CP, kg & 12.2 & 12.1 & 13.4 & 0.63 & 0.31 \\
Fat, kg & 6.11 & 7.56 & 5.04 & 1.04 & 0.24 \\
\hline
\end{tabular}

${ }^{1}$ Treatments: CON (control) $=446 \mathrm{~g}(\mathrm{DM})$ of a conventional MR $(20 \%$ $\mathrm{CP}, 20 \%$ fat), MOD (moderate) $=669 \mathrm{~g}$ (DM) of a moderately high protein MR (26\% CP, 18\% fat), and AGG (aggressive) $=892 \mathrm{~g}(\mathrm{DM})$ of a moderately high protein MR ( $26 \% \mathrm{CP}, 18 \%$ fat). 
composition. This method can be used in studies feeding greater amounts of protein or more milk to calves to accurately determine the effects of these feeding programs on body composition while using a small number of animals and eliminating the need for direct chemical analysis. Using $\mathrm{D}_{2} \mathrm{O}$ may be an easy, inexpensive, and valid method for determining the composition of growth in calves fed these aggressive MR feeding programs. The $\mathrm{D}_{2} \mathrm{O}$ dilution method with analysis by NMR is an appropriate and easy method to estimate water, protein, ash, and fat, in young heifers.

\section{ACKNOWLEDGMENTS}

The authors thank George Walker Fund and the New Hampshire Agricultural Experiment Station. This is Scientific Contribution Number 2682. This work was supported by the USDA National Institute of Food and Agriculture (Washington, DC; NC-2042; accession number 1001283). The authors also thank the Fairchild Teaching and Research Center (University of New Hampshire) staff for use of the animals and assistance throughout the study. The NMR data were collected using the Varian Inova $500 \mathrm{MHz} \mathrm{NMR}$ housed within the University Instrumentation Center at the University of New Hampshire in Durham.

\section{REFERENCES}

Andrew, S. M., R. A. Erdman, and D. R. Waldo. 1995. Prediction of body composition of dairy cows at three physiological stages from deuterium oxide and urea dilution. J. Dairy Sci. 78:1083-1095.

Auchtung, T. L., D. J. Baer, R. A. Erdman, S. M. Barao, and G. E. Dahl. 2002. Relation of growth hormone response to growth hormone-releasing hormone to estimation of milk production via deuterium oxide dilution in beef cattle. J. Anim. Sci. 80:1270-1274.

Bartlett, K. S., F. K. McKeith, M. J. VanderHaar, G. E. Dahl, and J. K. Drackley. 2006. Growth and body composition of dairy calves fed milk replacers containing different amounts of protein at two feeding rates. J. Anim. Sci. 84:1454-1467.

Blome, R. M., J. K. Drackley, F. K. Keith, M. F. Hutjens, and G. C. McCoy. 2003. Growth, nutrient utilization, and body composition of dairy calves fed milk replacers fed different amounts of protein. J. Anim. Sci. 81:1641-1655.

Byers, F. M. 1979. Measurement of protein and fat accretion in growing beef cattle through isotope cattle procedures. Ohio Beef Cattle Reg. Progress Rep. Anim. Sci. Ser. 79. Ohio Agric. Res. Dev. Cen., Wooster.

Chapman, C. E., T. M. Hill, D. R. Elder, and P. S. Erickson. 2017. Nitrogen utilization, preweaning nutrient digestibility, and growth effects of Holstein dairy calves fed 2 amounts of a moderately high protein or conventional milk replacer. J. Dairy Sci. 100:279-292.

Diaz, M. C. M. E. Van Amburgh, J. M. Smith, J. M. Kelsey, and E. L. Hutten. 2001. Composition of growth of Holstein calves fed milk replacer from birth to 105-kilogram body weight. J. Dairy Sci. 84:830-842.

Fulmer, G. R., A. J. M. Miller, N. H. Sherden, H. E. Gottlieb, A. Nudelmans, B. M. Stoltz, J. E. Bercaw, and K. I. Goldberg. 2010. NMR chemical shifts of trace impurities: Common laboratory solvents, organics, and gases in deuterated solvents relevant to the organometallic chemist. Organometallics 29:2176-2179.

Jesse, G. W. G. B. Thompson, J. L. Clark, H. B. Hedrick, and K. G. Weimer. 1976. Effects of ration energy and slaughter weight on composition of empty body and carcass gain of beef cattle. J. Anim. Sci. 43:418-425.

Khaled, M. A., H. C. Lukaski, and C. L. Watkins. 1987. Determination of total body water by deuterium NMR. Am. J. Clin. Nutr. 45:1-6.

Novak, L. P. 1967. Total body water. Pages 197-216 in Compartments, pools and spaces in medical physiology. U.S. Atomic Energy Commission, Oak Ridge TN.

Panaretto, B. A., and A. R. Till. 1963. Body composition in vivo. II. The composition of mature goats and its relationship to the antipyrine, tritiated water, and $\mathrm{N}$-acetyl-4-aminoantipyrine spaces. Aust. J. Agric. Res. 14:926-943.

Rius, A. G., E. E. Connor, A. V. Capuco, P. E. Kendall, T. L. Auchtung-Montgomery, and G. E. Dahl. 2005. Long-day photoperiod that enhances puberty does not limit body growth in Holstein heifers. J. Dairy Sci. 88:4356-4365.

Schoeller, D. A., E. van Santen, D. W. Peterson, W. Dietz, J. Jaspan, and P. D. Klein. 1980. Total body water measurement in humans with ${ }^{18} \mathrm{O}$ and ${ }^{2} \mathrm{H}$ labeled water. Am. J. Clin. Nutr. 33:2686-2693.

Shields, R. G., D. C. Mahan, and F. M. Byers. 1983. Efficacy of deuterium oxide to estimate body composition of growing swine. J. Anim. Sci. 57:66-73.

Shipley, R. A., and R. E. Clark. 1972. Tracer Methods for In Vivo Kinetics: Theory and Applications. Academic Press, London, UK.

Tikofsky, J. N., M. E. Van Amburgh, and D. A. Ross. 2001. Effect of varying carbohydrate and fat content of milk replacer on body composition of Holstein bull calves. J. Anim. Sci. 79:2260-2267.

Woodford, S. T., M. R. Murphy, and C. L. Davis. 1984. Water dynamics of dairy cattle as affected by initiation of lactation and feed intake. J. Dairy Sci. 67:2336-2343. 